\title{
The work-intensive fiction of frictionless trade in the Angolan port of Lobito
}

\author{
Jon Schubert
}

\begin{abstract}
Cargo shipping, as emblematic stand-in for globalization, peddles a seductive imagery of frictionless transnational trade and just-in-time logistics. Backed by the normative might of transnational institutions, instruments such as UNCTAD's Automated System for Customs Data (ASYCUDA) are being rolled out across "developing countries," promising the rationalization, acceleration, and "dematerialization" of customs processing, while countries themselves introduce efficiency reforms to smoothen the flow of goods. This article charts the intensive work required to produce this fantasy of frictionless trade around the Atlantic port of Lobito, Angola. In a context where imports have dropped by 50 percent to 60 percent since 2014 due to lower oil prices, this article traces how actors involved in making this import-dependent economy work deal with the seeming failure of promises of transnationally connected economic growth.
\end{abstract}

Keywords: Angola, ASYCUDA, crisis, customs, import-dependency, seaports, shipping

Frictionless global trade is both a precondition and an ideological foundation of what is commonly and ahistorically glossed as globalization. In this narrative, the increasingly cost-effective outsourcing and reallocation of manufacturing across the globe is a "win-win" situation that allows "poorer countries" to play out their main competitive advantage-lower labor and production costs-while reducing end consumer prices and increasing corporate profits through arbitrage (Cowen 2014: 58). In line with this theme section's call to ethnographically investigate the complex technological machinery and human labor required to move the goods along the maritime logistics chain, this article looks at the considerable work involved in producing and upholding this seductive imagery of frictionless global trade.

More specifically, in the context of Angola, the article examines the tensions that arise from the gap between the promises by technical and regulatory reforms to facilitate customs declarations and speed up maritime imports and the increasingly grim realities of a blocked import economy almost at a standstill. Focusing on the way importers, customs brokers (despachantes), and customs agents improvise to straddle the new efficiency imperatives of technical and regu- 
latory innovation amidst inflation and dwindling foreign exchange reserves, this article charts the intensive labor required to make goods flow.

Indeed, for the container economies under scrutiny in this issue, the port of destination is, barring transshipment and cabotage, not only a physical port but most often also a port of entry into a national territory. For goods to move across the sea, someone has to order them, pay for their shipping, and receive them. However, to retrieve the goods from the port, they have to be cleared through customs. And this whole process-from order and payment to declaration and clearance-presents substantial challenges to those who are working to bring the goods in.

Anthropological scholarship has cautioned us to see both "the national economy" and "the global economy" as ideological constructions, especially when renewed attention has been placed on the unreliability of macro-economic indicators in Africa (Jerven 2013). Following Hannah Appel, we need to ask ourselves how "national economies become both intelligible, possessing representational unity or naturalized authority, and compelling - the stuff of fantasy and desire, power and subjugation" (2017: 295) - and the same kind of questions must be asked about "the global economy," too.

My analysis is set in Lobito, on the Angolan central coast. The port of Lobito is, in comparison with massive transshipment ports such as Algeciras (Leivestad, this issue), Singapore, or Santos, but a secondary port on the Southern Atlantic. Its historical importance and ongoing centrality to regional economic life and in initiatives designed to smoothen the business of imports in Angola, however, make it an apposite site to investigate the work-intensive production of seemingly frictionless circulation. Seaports at the margins are central to global projects of circulation that, while claiming universal connectivity, are "profoundly dependent on the uneven terrains of global capitalism" (Stenmanns 2019: $850)$.

The Angolan context can help us tease out this unevenness precisely because the business of imports in a context of crisis is fraught with so many frictions. Ports are often represented as "portals" or "nodes" of globalization or as "seamless bridges for flows" (Rothenberg 2018). As such, they are good to think with about what this global economy is and the substantial work that is required to make it appear as something given and coherent that just flows frictionless across borders and regulatory regimes.

This material is part of an ongoing research project seeking to disaggregate the commodity crisis and its impact on an import-dependent African economy such as Angola. It is based on interviews and observations carried out in Lobito over five months since May 2018, and informed by my research in Angola since 2007. As such, the article is also a rejoinder to Ruy Llera Blanes' thoughts about the "unnameability of austerity" in Angola in an earlier issue of Focaal (2019).

After a discussion of supply chain capitalism and the role of states, specifically through ports and customs, I briefly sketch out the Angolan context, detailing how political changes, cycles of resource-dependent boom and bust, and the more recent introduction of ASYCUDA, the United Nations Conference on Trade and Development's (UNCTAD) Automated System for Customs Data, have all profoundly reshaped the conditions for the business of maritime cargo. The article then ethnographically zooms in on the business of imports, first from the perspective of food importers, then from the viewpoint of customs agents and customs brokers, to investigate how the relationship between global logistical dis/orders and sovereign compromises is reshaped through efficiency reforms and economic crisis.

Through this, the article analyzes one of the key nodes of the maritime supply chain - the port of entry-and sketches out a larger argument about the seeming inescapability of the homogenizing ambitions of contemporary supply chain capitalism. The frictionless global container economy, in this context, is revealed as a convenient fiction that requires intensive work and improvisation. This includes strategies of 
concealment and visibility that serve to uphold certain ideas as natural and self-evident, while obscuring other, less unambiguously "desirable" practices and outcomes that are equally necessary to maintain the flow of goods.

\section{States and supply chain capitalism}

Representing transnational flows and the disappearance of borders as a natural consequence of the increasing speed and connectivity brought about by "globalization" (Appadurai 1990; for a critique, see Heyman and Campbell 2009; or Rockefeller 2015), obscures both the individual agency and the complex regulatory architecture required to produce these flows. Yet this misrepresentation has become so dominant as to become almost unquestioningly believed and reproduced by a large public, including by politicians of all stripes across the globe (cf. Carse et al. 2020: 3).

However, as for example the UK parliament's increasingly absurd convolutions over the "Irish Backstop" in 2019 showed, the free flow of goods is not a natural state of things. Barring elaborate regulatory frameworks such as a common market, ports of entry are "chokepoints" of national sovereignty (Dua 2018). Goods transition from one regulatory regime to another and are subjected to controls and duties. Actively challenging the "the neoliberal myth that circulation is essentially born free but everywhere in chains" forces us "to render visible the many hands meddling in the world to make things move" (Schouten et al. 2019: 780).

The container as the box that made the logistics revolution possible "marks not just the fetish of 'network' and 'flow' designs but moreover, its transductive value as a mediator of inputs and outputs" (Chu et al. 2020, see also Leivestad, this issue). However, despite the centrality of supply chain logistics to contemporary capitalism, the operations that move this box largely remain a black box. Research in critical logistics has sought to remedy this situation and to study logistics as a way to examine contemporary capitalism in all its unevenness. Indeed, "global circulation rests on a vast range of sociotechnical arrangements, relations and practices" that not only involve international treaties and norms for technical harmonization but are also "a matter of day-to-day work on recalcitrant people and objects" (Stenmanns and Ouma 2015: 98), and ethnographic research especially has sought to center that dayto-day work in its analysis. Soundly rejecting the field of logistics' "self-depiction as an apolitical science of circulation" (Chua et al. 2018: 625) and focusing instead on the inequalities, violence, and power disparities produced through supply chain capitalism, such scholarship has highlighted where and how states intervene strategically, and how state sovereignty has been reconfigured and recast under the pressures and needs of the global supply chain.

As the interface between "the global" and national territories, customs services play a central role here. In the case of Ghana, Brenda Chalfin has documented extensively how the customs standards, through processes of global harmonization, "emerge as key sites for the production of new criteria of statehood and new forms of sovereignty" (2006: 243). These processes Chalfin sees as closely tied to the advance of neoliberal agendas. Similarly, for China, Julie Chu details how the imperative to facilitate export flows and attract foreign direct investment (FDI) "has dramatically transformed customs from a marginal bureau of last resort, where the least competent state workers often ended up, to one of the most prominent and selective departments," deeply affecting the professional and political subjectivities of customs agents (2019: 203). Deborah Cowen (2010) elegantly describes the effects of the tension between geopolitical (read: international security) and logistical (read: the need for speed and seamless connections) models of spatial calculation on US institutions and policy making, while Julian Stenmanns applies a similar analytic on the "marginal" West African seaport of Freetown in Sierra Leone (2019).

The argument I advance here is that in "developing" countries-and especially African countries-scripted as corrupt and lacking the capac- 
ities to implement safety and security measures "correctly," technical solutions and managerial governance reforms are viewed as a panacea for the ills that plague their ports and customs services. The case of Angola shows how such reforms can at the same time "fail" and be "successful." A reform such as the ones under scrutiny here might fail to fulfill its stated goals of smoothing the flows of imports-but as it "relies on and props up select sectors of the state apparatus" (Chalfin 2010: 575), it might still reconfigure the state's capacities and competences. ${ }^{1}$

The Angolan case, however, highlights that beyond the realm of state agents such as customs agents, a considerable amount of work is necessary to conceal the frictions between the ambitions of global free flows and messy sociopolitical realities at the chokepoint-a sleight of hand that relies on strategies of visibility and invisibility to uphold certain ideas as natural and self-evident, precisely by occulting a host of other social practices that are equally necessary to keep the flow of goods coming. Producing and upholding this fiction serves particular economic and political interests, while conveniently obscuring histories of inequality, violence, and resource-dependency. And as Leivestad and Markkula discuss in their introduction to this theme section, the global shipping industry itself operates by this dual logic: speed and costeffectiveness conveniently eclipse more unsavory practices like flags of convenience, labor abuses, price dumping through arbitrage, and environmental damage.

\section{Reviving the Lobito Corridor}

While neighboring Benguela, the capital of the eponymous province, had been a center of the Atlantic (slave) trade since the early 1600s, Lobito is very much the product of twentieth-century colonial extractive capitalism. Construction on the port started in 1903, soon followed by work to build a railway. Known by its Portuguese name Caminho de Ferro de Benguela as the CFB, its 1,544-kilometer rail link stretched from the
Atlantic coast to the country's eastern border. By 1931, the CFB connected the port of Lobito with the mineral heartlands of Katanga in the Belgian Congo (today the Democratic Republic of Congo, DRC) and the (then Southern Rhodesian) Zambian Copperbelt (Duarte et al. 2015; Hance and van Dongen 1956).

From the start, the Lobito Corridor was geared toward bringing African raw materials to Europe's industrial heartlands, an extractive logic replicated across the continent by colonial-era hinterland-to-coast rail corridors (Debrie and de Guio 2004: 22-23). The volume of goods moving through the port and railway grew steadily during the twentieth century, peaking in 1972manganese and copper from the neighboring countries, and iron, sisal, maize, wheat, bananas, and coffee from the Angolan highlands. In exchange, consumer goods entered the port and were distributed inland.

Following a protracted, brutal anticolonial liberation war (1961-1974), independence in 1975 was a watershed, as immediately after independence Angola plunged into a civil war, which lasted, with some shorter interruptions, until 2002. While the volume of transactions through the port and railway continued at a comparable level till 1977, the combination of socialist planned economy and civil war soon led to a steep decline in exports. Cut off from the hinterland, the government increasingly relied on the export of offshore oil to finance the war effort, producing the extreme oil-dependency that persists until today.

\section{An import-dependent container economy}

From a port geared toward exports Lobito (and by extension Angola) shifted to an importdependent container economy. Since the early 1980s, "I have a container coming in" indexed an upturn in individual and collective fortunes, with imports not only the lifeline of the government-controlled parts of the country but also a ticket to personal advancement. With domestic agricultural and industrial production interrupted by the war, container shipping en- 
abled the import of essential goods and military equipment and of premium consumer goods for a small nomenklatura and oil expats-access to which could be bartered and exchanged for favors. ${ }^{2}$ Like elsewhere, containerization also reduced the footprint of the port in Lobitangan social life: previously sailors on shore leave for several nights enjoyed lively nightlife in bairro Canata, and local entrepreneurs had made fortunes in ship chandling; now ships stayed (ideally) for a few hours at most, and insurance and security concerns prevented crew from leaving the port area. ${ }^{3}$

After two decades in the doldrums, the end of the war in 2002 heralded the beginning of national reconstruction. Coinciding with the onset of a new commodity supercycle and growing demand from Asian countries, oil production expanded. With barrel prices at 60 to 110 USD for most of the decade and production around 1.5 to 1.6 million barrels per day, Angola was flush with oil money. Contrary to many other African countries, Angola was able to rebuild on its own terms, without conditional donor assistance. Rehabilitating the CFB line and the port of Lobito was at the heart of the govern- ment's ambitious schemes, a prestige project to show the world that Angola could do things "on its own" and to diversify the national economy away from oil production (which still makes up 90 percent of government revenue).

But while the port of Lobito after its upgrading boasts impressive, state-of-the art equipment, there was, during the period of fieldwork (2018-2019) almost no cargo coming in, much less going out. The little work was being carried out by the single multimodal crane, or the ships' own cranes, as all but one of the new Chinese cranes procured by the government through oilfor-infrastructures deals were standing stillthis fault was variously explained as being due to lack of maintenance, missing spares, corruption in the procurement process, or the general unreliability of the Angolan power grid.

The dry port was empty, despite having been inaugurated twice with great pomp ahead of elections by the former president, José Eduardo dos Santos. The minerals terminal lay unused, and the promised new mineral exports from Katanga had only materialized at a much smaller scale than projected, owing to the deficient rail network in DRC.

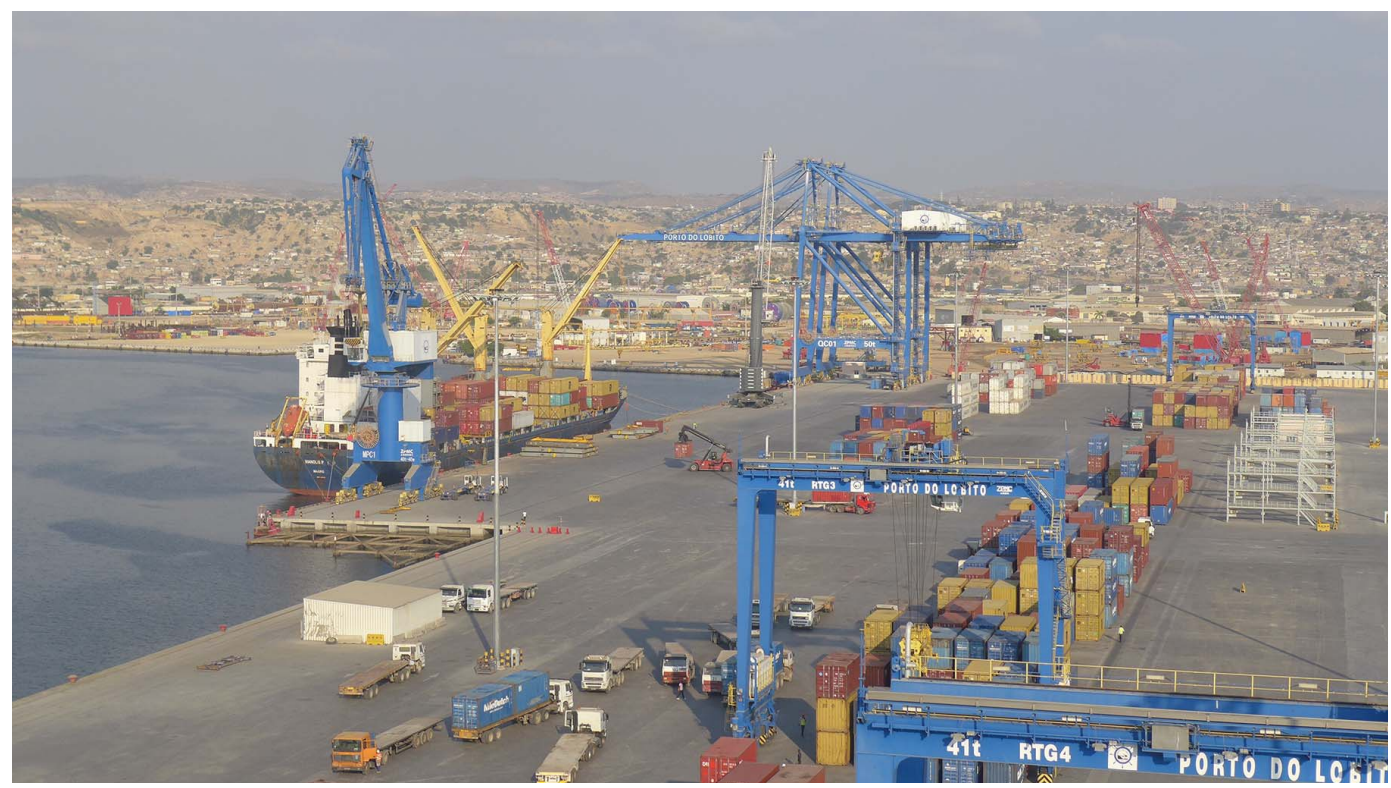

FIGURE 1. Largely empty quays. Photo by Jon Schubert, June 2019. 


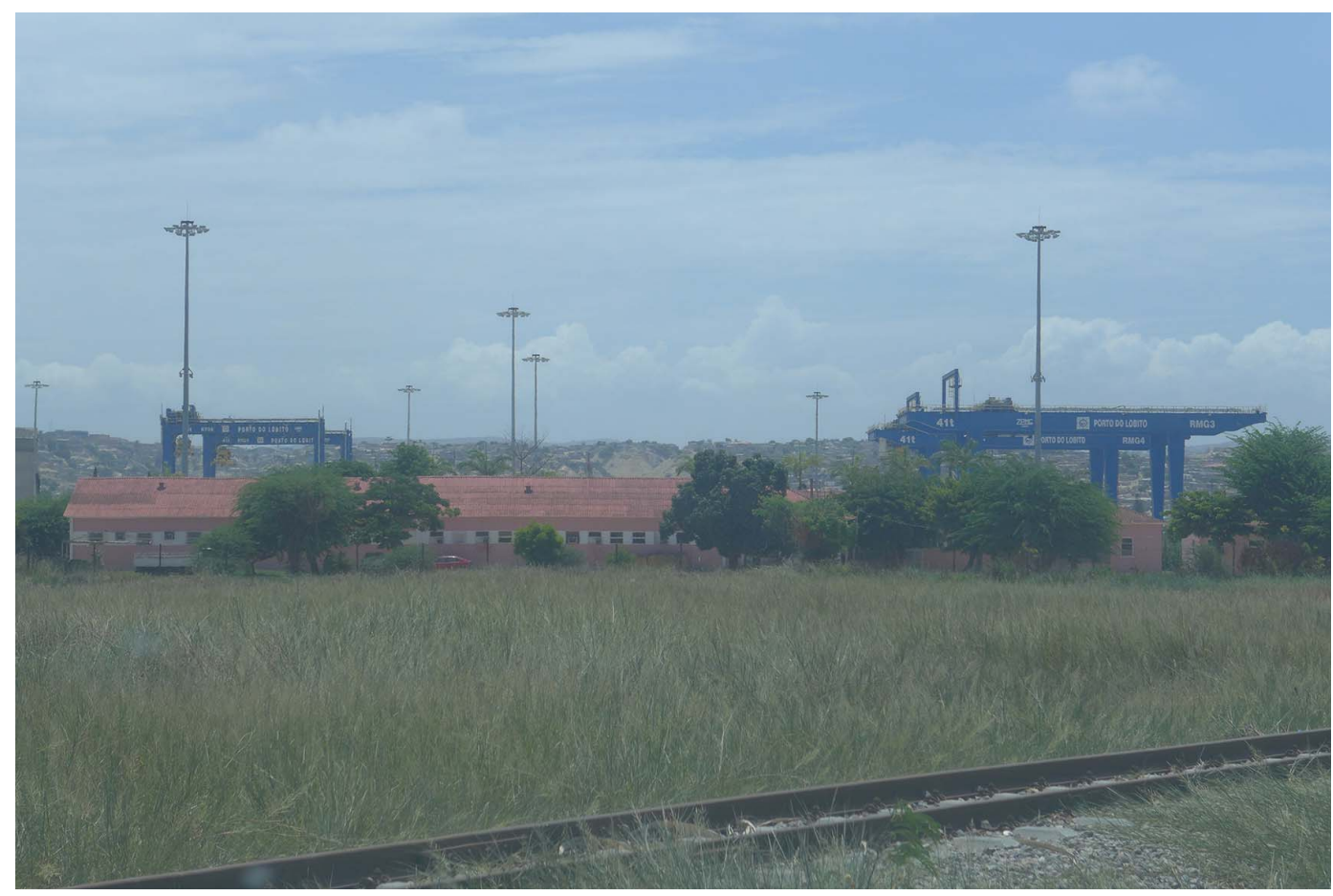

Figure 2. The dry port was empty. Photo by Jon Schubert, June 2019.

This dismal state of affairs, interlocutors agreed unanimously, was a result of the crisisa calamity that befell Angola in late 2014, when the price of a barrel of Brent crude oil dropped from about 110 USD to 62 USD, fluctuating between 60 and 35 USD per barrel for most of 2015 through 2017. With oil accounting for 90 percent of exports and 75 percent of government revenue, the country plunged into a deep recession: rising inflation, a steep depreciation of the national currency, the kwanza, and the elimination of subsidies on fuel, hit the poorer parts of the population hardest. And despite a slight, temporary recovery of oil prices in 2018 , the crisis has only deepened from 2018 to 2020: the population has no money, and a serious dollar shortage left importers struggling to pay for their goods. Most of my interlocutors estimated that since 2014, the volume of goods imported had dropped between 50 percent and 60 percent.

In the view of the Angolan government and the port of Lobito's users, however, Lobito has the potential to become Angola's most important port again, thanks to these multibilliondollar investments and the reestablished if underutilized transborder rail link. Accordingly, hopes for economic development and measures to revitalize and diversify the economy also crystallize around its shiny new installations. Its unused cranes and quays eerily empty of container stacks are stark reminders of the vulnerabilities of container economies and the (localized) physical slowing down of global supply chains.

\section{ASYCUDA in Lobito}

Although the port of the capital, Luanda, remains at the time of writing Angola's biggest port in terms of volume, Lobito is still the poster child of Angolan port modernization. As such, it was chosen to serve, from early 2017 on, as the pilot project for the phased introduction of ASYCUDA to Angola.

ASYCUDA, the Automated System for Customs Data, is the United Nations Conference on 


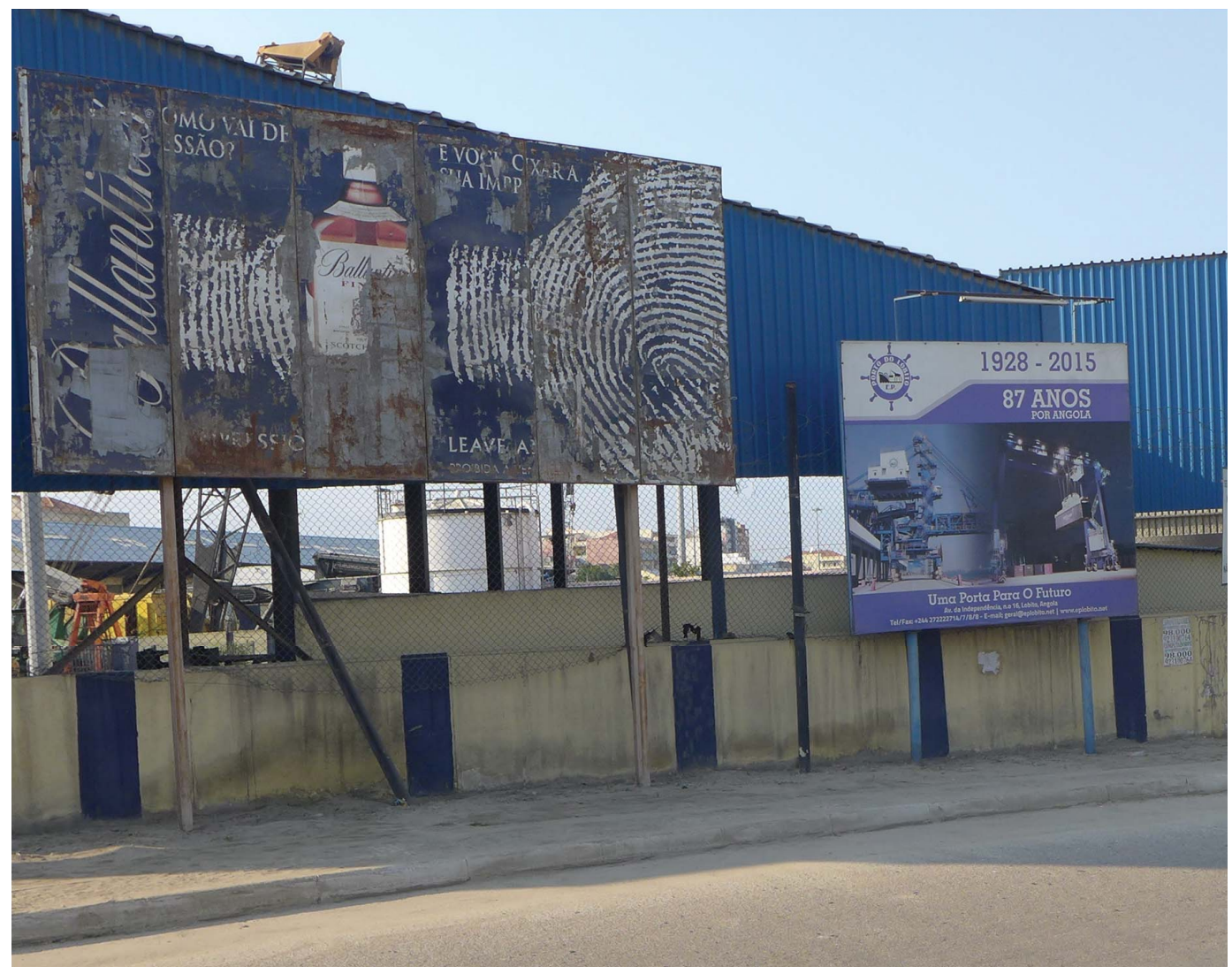

Figure 3. Porto de Lobito, 1928-2015: "87 years for Angola. A door to the future." Jon Schubert, June 2019.

Trade and Development's (UNCTAD) largest technical assistance program, and is currently being implemented in "over 90 countries, territories and regions" (ASYCUDA n.d.). Though ASYCUDA is not a reform in itself, it is a technical tool designed to support and facilitate profound customs reforms to be negotiated between national authorities and UNCTAD (Cantens 2007: 290). Much as it is presented as technical assistance, ASYCUDA is but the latest step in a longer process of global customs harmonization. This is a process that Brenda Chalfin sees as both "closely tied to the advance of neoliberal economic agendas ... [and] provide[s] a cover for shifts in the expression and location of state power on a global scale" (Chalfin 2006: 243); Deborah Cowen places more emphasis on security imperatives and programs that "seek to govern integrated global economic space while at the same time retaining politically differentiated sovereign territories (Cowen 2014: 81).

Couched in the technical language of "removing barriers to trade," UNCTAD reports operate on the basis of an aspirational, modernizing "but also" rhetoric. According to this logic, ASYCUDA serves as a panacea for "developing countries" that will not only "facilitat[e] trade efficiency and competitiveness by substantially reducing transaction time and costs"-arguably its main goal-but also improve revenue collection, reduce corruption, increase security, and even promote "sustainable development by cutting down on the use of paper, through the use of electronic transactions and documents" (UNCTAD n.d.). 
A double, mutually beneficial logic of visibility and concealment is at play here: on a transnational level, the touted benefits of customs rationalization occult the massively unequal terms of trade and resource-dependency that characterize African economies' insertion into world markets (cf. Taylor 2016); at national level, it allows the Angolan government to enthusiastically embrace efficiency reforms that were visible to and well-received by international investors while eschewing more profound structural reforms to its oil-dependent, rentier political economy.

\section{Smoothing the flows of imports}

Indeed, while Angola, thanks to oil money, largely eschewed the usual donor conditionalities after the war, the government was very adroit in successfully positioning the country as a business-friendly and stable destination for FDI. This success owed more to the ready availability of vast sums of no-strings-attached oil money pouring into construction and banking than to effective reforms (cf. Ennes Ferreira and Soares de Oliveira 2019), but still: Angola was, until the downturn in oil prices, considered a stable, attractive destination for FDI, regardless of any possible democratic deficiencies and human rights abuses. And some of this attractiveness was also a result of the government's successful adoption of a language of market efficiency and embrace of managerial reforms to improve the "business environment" (this in itself often measured by proxy, such as the World Bank's "Ease of Doing Business" report and yearly rankings). This included the successive professionalization and modernization of the import regime.

In addition to the physical upgrading of the port of Lobito, new procedures and regulations to smoothen and accelerate the flow of imports were introduced. However, as the case of Angola highlights, there are serious limitations in simply implementing one-size-fits-all technicalmanagerial "fixes" to political and developmen- tal issues. ${ }^{4}$ Let's now first turn to some of these new import regulations, then look at how ASYCUDA worked in greater detail.

\section{Shifting import regulations}

"I have a headache with a vessel coming in," Raafe the supply chain manager said, "the first day you have to organize everything, the stevedores and the trucks, and there are always problems. Each additional day in port is twelve thousand dollars in demurrage. ${ }^{5}$ For the stevedores, it's more money, though." We were sitting over espresso and bottled water in the Lobito offices of one of Angola's largest, Lebanese-owned food importers, ${ }^{6}$ a company I will call LevantAngo.

LevantAngo established itself in Angola in the early 1990s with, as company lore has it, a single, maverick entrepreneur importing two containers of foodstuffs from his own savings. Now operating as subsidiary of the founder's family holding in Geneva and Dubai, LevantAngo's blue-and-white armazéns (warehouses) dominate the outskirts of all of Angola's major towns, supplying Eritrean, Mauritanian, and Gambian wholesalers, as well as Angolan market traders (cf. Inglês 2016: 223-224).

Raafe, was walking me through the steps of importing their supplies. To ensure constant levels of stores in LevantAngo's armazéns, Raafe had to keep an eye on the whole supply chain, the "pipeline" of imports, as he termed it, and where delays could mess up his entire chain (cf. Rothenberg 2018). His headaches were not only linked to material challenges-such as the port's faulty cranes, salary arrears among the workforce, fuel shortages affecting the whole province that led to stoppages at the trucking companies, and the persistent pilfering of unloading straps for break bulk by the stevedores-rather, the whole administrative and regulatory environment in Angola seemed to conspire against Raafe to constrain the flow of imports.

The main problem, precisely, was regulatory and linked to the state's reforms to improve the efficiency of imports and customs duty collec- 


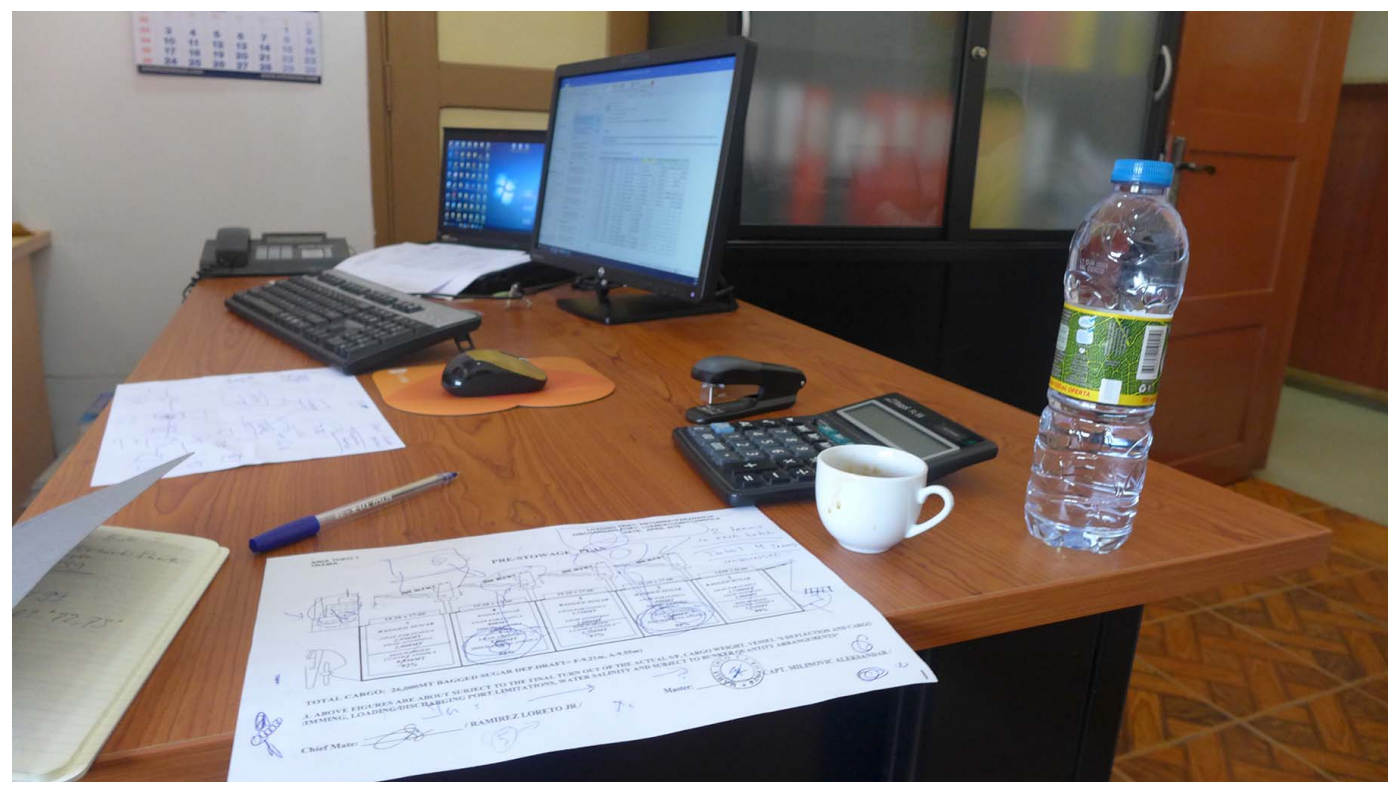

FIGURE 4. Controlling the "pipeline," Raafe's office. Photo by Jon Schubert, May 2019.

tion. As Raafe complained, "The government takes a decision but makes no studies, no workwe're a test field for them." One of the key issues, he explained, was the introduction of import permits, almost overnight, and the withholding of import licenses for certain types of goods which, according to the ministries in charge, could be produced locally rather than imported: "They take a decision, then they start noticing gaps. So we get a special permit."

Political goals set by decision-makers often willfully misrecognize the actual challenges of bringing in the goods (cf. my previously mentioned Brexit parallel), creating endless complications for those actors involved in physically getting containers into the country. Between vaping breaks, Raafe's office mate, Baqil, the commercial director for the Southern region reinforced:

They introduce new laws all the time. For example, fuba, maize flour, which is really essential to people's diet here, we're no longer allowed to import. [JS: And does the local production supply enough for the needs of the market?] No, they don't supply enough. They seek to be self-sufficient, but there's not enough production. The government has the right vision, but there's not enough foreign currency, no stable budget - the laws are good in principle, but they're passed and applied next Monday, and we have no stocks.

Another consequence of the crisis that directly impacted the way in which imports were organized was the introduction of letters of credit. Previously, importers could get dollars from their bank to pay their suppliers abroad, but after the oil price dropped in 2014, Angolan banks ran out of dollars when the National Bank of Angola (BNA) imposed stringent currency controls and restricted dollar sales to commercial banks. As a consequence, importers were sitting on mountains of kwanzas useless to import goods. Raafe and his colleagues were relatively lucky, as their holding company took a gamble and advanced the money to pay the suppliers.

The major government reform to ease the situation was to introduce letters of credit, whereby the bank endorses the importer's purchase. But, as Baqil explained, the plummeting 
value of kwanza made this very unpredictable, as between the moment that the bank issues the letter of credit and the moment it charges the importer for the dollar amount in kwanza, the kwanza will usually have lost value again: "When the kwanza is at 326 today, they'll issue the letter of credit based on that, but when the kwanza rises to 340 after three days, the bank will take more." Sure, importers could factor in a 5 percent buffer to compensate for that, "but still you'll have a surprise at the close of the year. In February [i.e., when the accounts are done] you'll see that most of the profit from the previous year is gone because of devaluation." The result of this, my Lebanese friends told me, is that consumer end prices have doubled, if not tripled since the onset of the crisis, while most wages have nominally remained the same.

Importers such as Raafe may well seek to control the smooth unfurling of the maritime supply chain through space and time (cf. Rothenberg 2018); customs agents may even actively support the business of speedy imports by reducing "unnecessary" inspections of low-risk goods (Chu 2019: 205) — crisis and oil-dependency, as in the case of Angola, seriously call into question the idea of an "all-seeing state" à la Chalfin, projecting its sovereign authority outward in time and space through a series of "spatio-temporal maneuvers" (Chalfin 2007: 1616). Rather, "the state" appears as a bricolage, an assemblage of contradictory impulses, interests, and capacities that is often more precarious than its sleek unitary façade projects.

\section{Dematerializing customs clearance}

Faced with such unpredictability, one might imagine that the introduction of ASYCUDA, with all its promises of smoothing the flows, would somewhat mitigate against these difficulties. However, Angola operates a regime of customs clearance inherited from the colonial regime, giving customs brokers/clearing agents (despachantes) a central role in clearing goods through customs. Much like lawyers represent their clients in court, customs brokers are inde- pendent, liberal professionals, admitted to the profession by a state examination, and habilitated to represent their clients before the customs authority. The main task of the despachante is to interpret the customs code on behalf of his or her client, submit a truthful declaration to the customs authority, act as intermediary for the payment of duties, and transmit the customs clearance to the client, who can then retrieve the goods from port.

According to Dr Kalissala, who was a provincial department head at the AGT (Administração Geral Tributária, i.e., general customs and taxes authority), the introduction of ASYCUDA was a great success and a point of pride for the AGT delegation in Lobito. For him, the new system sped up things considerably, as it did away with the need for despachantes to physically submit the paperwork to AGT.

The system also automatically categorizes merchandises into risk categories, based on the type of good, the country of origin, and the track record of the importer (i.e., whether they are to be trusted or not; cf. Cowen 2014: 87), and flags up those containers that need to be documentarily or physically inspected. The system also allows for the sharing of information between ports of entry across the national territory. Before that, Angola had already undergone a thorough customs reform, when its customs service had been largely managed by the British development consultancy Crown Agents. These had introduced yet another system, TIMS (Trade Information Management System), to Angola while implementing sweeping reforms to curb corruption and inefficiency.

For despachantes ASYCUDA did indeed speed up and "dematerialize" the process. In practice, however, the factors that created a headache for Raafe, also complicated life for the despachantes I spent time with. On a muggy Thursday afternoon, my friend Milton, an adjutant despachante running the business for a senior but largely absentee broker, invited me to accompany the clearance of a cargo in his office. He motioned me to sit down next to Dona (Mrs.) Elena, who did the preliminary work. Dona Elena launched 
ASYCUDA World-an internet explorer shortcut - and started explaining the system of registry numbers and category classifications. However, despite her repeated attempts, a pop-up window on the screen kept informing us that the system was unable to launch, as internet was down. And so, there was nothing much to be done for the rest of the day. Dona Elena packed up her things and suggested I came back to resume work the next morning.

The next morning, the system was up and running again, and Dona Elena walked me through a relatively simple despacho (declaration), the import of one container of iron sheets. This was easy, as it was one volume and one single category of goods, and within about 40 minutes, she had filled in and ticked all the required boxes in the online platform and made it ready for a final check by Milton. Meanwhile, her colleague at the desk in front of us had watched most of Godzilla and extensively browsed Facebook.

Milton's responsibility was to double-check what assistants like Dona Elena had filled in, especially regarding the classification of the goods, then attach the relevant documents to the file, and submit it to the AGT. Upon submission, the system automatically emits a nota de liquidação, a payment order for the customs broker to pay for customs and port fees on behalf of their client. As such, Milton agreed, ASYCUDA had brought about an economia processual, an economy of process, and simplified their lives. Rather than having to compute the percentages by hand and insert them into the old style, A3 forms with oversized typewriters, the system did most of that work automatically.

And yet, despite such an economy of process at the level of the clearing agents' offices and their direct interactions with the AGT, one can hardly speak of a "dematerialized" and frictionless flow of imports. Due to the dearth of imports and the vicissitudes of an unreliable IT architecture, Milton in fact often had time to break for coffee and pastries or go for drives across town to sort out all other kinds of private issues during his regular work hours. On one of these drives, as he was taking his wife, Cláudia, a customs agent,

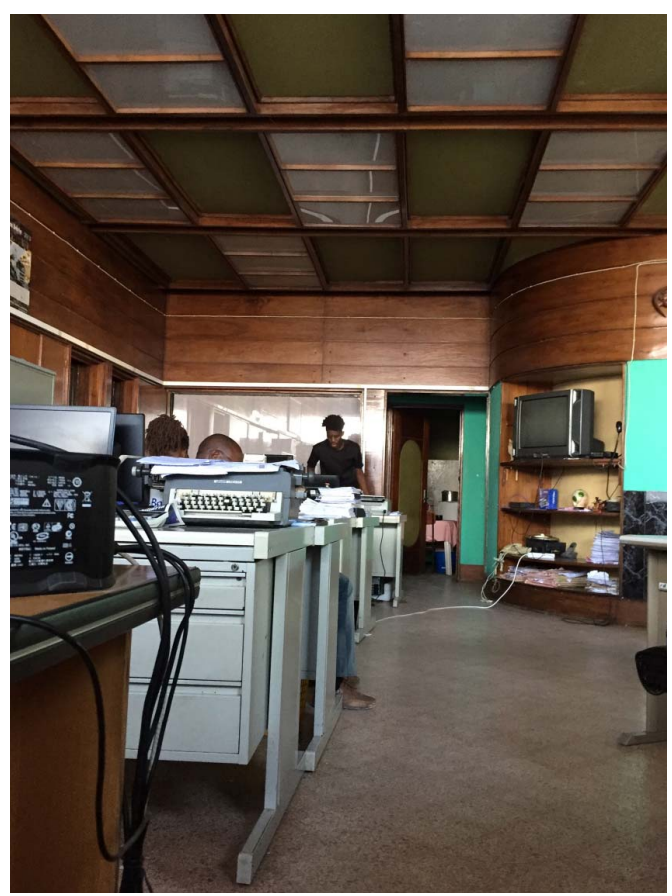

Figure 5. At a despachante's office. Photo by Jon Schubert, May 2018.

to a medical appointment up on the hill, they both reminisced about TIMS. Cláudia sighed: "I wish we'd kept TIMS. ASYCUDA is a good system but it's not adapted to Angolan realities." Milton continued: "You need really stable internet for this. And here we know how often 'there is no system' (cf. Schubert 2017: 4, 113). Yeah, someone can slack off and then tell his boss that there was no system, and what can a superior say? There's so often no system."

In addition to these previously mentioned material challenges to implementing ASYCUDA, producing a "modern" and efficient system of customs clearance to insert Lobito into the maritime supply chain requires adhesion to global standards of "good governance." These include technical practices and machineries, as well as security protocols devised to minimize the risks of smuggling, stowaways, and potential terrorist attacks to destination ports in the Global North (cf. Stenmanns 2019: 858). A modern, efficient customs service, holding itself to such global standards, should then by definition be 
clearly separated from the messiness of social life that surrounds it, so as to avoid corruption that would undermine safety, security, and due process. ${ }^{7}$ Both safety concerns and representing the free market as the most rational and efficient form of organizing exchange require strict, hygienic separation between agents of state bureaucracy and the self-interested actors of business.

The case of a customs agent married to a customs broker is but one, if rather obvious, example of how tenuous this separation is. In a small town like Lobito, it becomes more easily evident how most actors involved in the business of imports are intimately intermingled-sometimes connected through amorous or kinship ties or by having frequented the same high school, very often also by affiliation to the ruling party-but that is also true in more "developed" contexts (cf. Chu 2019: 207; Leivestad, this issue). Furthermore, in Angola, people often have to supplement their formal but insufficient wages with a side hustle or two that inevitably brings them in contact outside the formal procedures of a bythe-letter despacho. This reveals how porous the boundaries are between the realms of the regulatory state and the regulated importer. Modern, "dematerialized" customs clearance is presented as the rational, efficient way to speed up imports; inconsistencies and arbitrary-seeming changes to the import regime require constant improvisation and the mobilization of personal connections (Schubert 2019) to deal with bottlenecks and constrictions to the flow of goods.

\section{Concluding thoughts}

Representing capitalism as the natural state of things relies on elaborate practices of concealment and revealing-concealing certain risks while pricing others, for example (Mannov, this issue), or, on a grander, more totalizing scale, presenting trade as an exchange "that makes everyone better off" while concealing the fundamental violence of exploitation and dispossession.
Given everyday challenges, such as a plummeting kwanza and falling wages, unreliable internet, and ever-changing rules and regulations, smoothing the flow of imports in Lobito is hard work, requiring constant improvisation. And while the effects of these complications are directly felt in Lobito itself, where consumer end prices have been rising steadily since 2015 , bottlenecks at the chokepoint reverberate along the entire maritime supply chain.

In the form of ASYCUDA, a technical fix to reconcile the contradictory imperatives of frictionless flow and improved control and security is being rolled out across the "developing world," backed by the normative might of the United Nations' technical development assistance body, UNCTAD. Designed to remove the last remaining obstacles to frictionless trade across Africa, managerial, technological fixes, such as the electronic submission and processing of customs declarations promise to insulate actors of supply chain capitalism against "less aseptic - and more pernicious-political incentives" (Hönke and Cuesta-Fernandez 2018: 254).

The Angolan government's uneven, seemingly haphazard reforms to accelerate and facilitate the business of imports as seen through the lens of Lobito exemplify how precarious such fixes are: while the idea of frictionless global cargo flows has indeed become so dominant as to become naturalized even among socialisttrained public functionaries, realizing its promises is far from natural or self-evident. Despite the promises of dematerialization held up, mirage-like, by technical fixes such as ASYCUDA along the supply chain, a situation like Angola's invites us to pay renewed attention to the materiality of the flow of goods and to the possibilities and unexpected social fixes that open up at "sites of its coagulation" (Chua 2014).

In this secondary port city on the Southern Atlantic, the state-owned and state-managed port of Lobito was recently revamped. A cumbersome state bureaucracy has introduced seemingly haphazard reforms. The dearth of foreign exchange produces a "challenging economic climate." All these factors appear adverse to "the 
market's needs" and requirements for efficiency and speed, making the work of maritime imports particularly complicated. Keeping the goods flowing, especially in a context of crisis, requires constant improvisation, a healthy measure of fatalism, and the active cultivation of social ties across supposedly impermeable separations between "apolitical," technical services and "self-interested" commercial actors. Upholding the fiction of frictionless global trade requires, at every waypoint of the container economy, substantial ideological, political, affective, ${ }^{8}$ and practical work.

\section{Acknowledgments}

Research for this article was funded by the Leverhulme Trust as a Leverhulme Early Career Fellowship (ECF-2017-569) and benefited from institutional support from Instituto Superior Politécnico Jean Piaget de Benguela, Instituto Superior Politécnico Lusíada de Benguela, and the Centre of African Studies at the Catholic University of Angola (UCAN). I am grateful to my interlocutors in Angola, the editors and contributors to this theme section, as well as to the journal editors and anonymous reviewers at Focaal for their extremely valuable comments to this piece; many thanks also to Ana Duarte and Agathe Mora for their input on earlier versions of the article.

Jon Schubert is currently a Leverhulme early career fellow at the Department of Anthropology, Brunel University London, UK, where he is carrying out research on infrastructures, maritime imports, and crisis in Lobito, Angola. He has held research and teaching positions at the universities of Leipzig, Sussex, and the Graduate Institute, Geneva, and has worked in commercial risk forecasting and foreign affairs. He has extensive ethnographic fieldwork experience in Angola and Mozambique. He is the author of Working the system: A political ethnography of the New Angola (Cornell University Press
2017) and co-editor of Extractive industries and changing state dynamics in Africa: Beyond the resource curse (Routledge 2018). orcid.org/0000-0003-1100-8086 E-mail: jon.schubert@brunel.ac.uk

\section{Notes}

1. I develop a similar line of reasoning about the co-production of sovereignty in greater detail for the mining sector in Mozambique in Schubert (2018).

2. I discuss these bartering practices in greater detail in Schubert (2017: 124); see also Auerbach (2020: 19).

3. As discussed by Johanna Markkula and illustrated by the fitter's lament opening her article (this issue).

4. Agathe Mora (2020) describes very similar inherent contradictions at play in rule of law reforms implemented by international bodies in postwar Kosovo.

5. Charges for exceeding the contractually agreed lay time in port.

6. Technically, of FMCG, Fast-Moving Consumer Goods sold in bulk and with a very small margin of profit on large volumes, including durable food and beverage basics but also soap, washing powder, household detergents, and healthcare products like toothpaste.

7. This is, by the way, why in many countries, customs agents are organised in corps that regularly rotate location, precisely to prevent too much familiarity with local social networks.

8. On affective work, see especially also Mannov, and Markkula (both this issue).

\section{References}

Appadurai, Arjun. 1990. "Disjuncture and difference in the global cultural economy." Theory, Culture \& Society 7: 295-310.

Appel, Hannah. 2017. “Toward an ethnography of the national economy." Cultural Anthropology 32 (2): 294-322.

ASYCUDA. n.d. "ASYCUDA-User Countries." https://asycuda.org/en/user-countries/ (accessed June 26, 2019). 
Auerbach, Jess. 2020. From water to wine: Becoming middle class in Angola. Toronto: University of Toronto Press.

Blanes, Ruy Llera. 2019. "Austerity en route, from Lisbon to Luanda." Focaal (83): 37-50.

Cantens, Thomas. 2007. "La réforme de la douane camerounaise à l'aide d'un logiciel des Nations unies ou l'appropriation d'un outil de finances publiques" ["The reform of Cameroonian customs with the help of a United Nations software or the appropriation of a tool of public finances"]. Afrique contemporaine 223-224 (3): 289-307.

Carse, Ashley, Townsend Middleton, Jason Cons, Jatin Dua, Gabriela Valdivia, and Elizabeth Cullen Dunn. 2020. "Chokepoints: Anthropologies of the constricted contemporary." Ethnos. https:// doi.org/10.1080/00141844.2019.1696862.

Chalfin, Brenda. 2006. "Global customs regimes and the traffic in sovereignty: Enlarging the anthropology of the state." Current Anthropology 47 (2): 243-276.

Chalfin, Brenda. 2007. "Customs regimes and the materiality of global mobility: Governing the port of Rotterdam." American Behavioral Scientist 50 (12): 1610-1630.

Chalfin, Brenda. 2010. "Recasting maritime governance in Ghana: The neo-developmental state and the port of Tema." The Journal of Modern African Studies 48 (4): 573-598.

Chu, Julie Y. 2019. "Risky work, fateful play: Chinese customs inspectors and the compossibility of fortune." Ethnos 84 (2): 201-222.

Chu, Julie Y., Philana Woo, Kenzell Huggins, Heangjin Park, Harini Kumar, and Jack Mullee. 2020. "Un/boxing fulfillment: A field guide to logistical worlds \#roadsides." OA e-journal Allegralaboratory, 31 March 2020. https://allegralaboratory .net/un-boxing-fulfillment-a-field-guide-tologistical-worlds/.

Chua, Charmaine. 2014. "Logistics, capitalist circulation, chokepoints." The Disorder Of Things (blog), 9 September 2014. https:// thedisorderofthings.com/2014/09/09/ logistics-capitalist-circulation-chokepoints/.

Chua, Charmaine, Martin Danyluk, Deborah Cowen, and Laleh Khalili. 2018. "Introduction. Turbulent circulation: Building a critical engagement with logistics." Environment and Planning D: Society and Space 36 (4): 617-629.

Cowen, Deborah. 2010. "A geography of logistics: Market authority and the security of supply chains." Annals of the Association of American Geographers 100 (3): 600-620.

Cowen, Deborah. 2014. The deadly life of logistics. Minneapolis: University of Minnesota Press.

Debrie, Jean, and Sandrine de Guio. 2004. "Interfaces portuaires et compositions spatiales: Instabilités africaines" ["Port interfaces and spatial compositions: African instabilites"]. Autrepart 32 (4): 21-36.

Dua, Jatin. 2018. "Chokepoint sovereignty." Limn 10: Chokepoints. https://limn.it/articles/ chokepoint-sovereignty/.

Duarte, Ana Maria Simões Ramalho, Fernando Pacheco, Regina Santos, and Elling N. Tjønneland. 2015. "Diversification and development, or 'white elephants'? Transport in Angola's Lobito Corridor." 2015: 7. CMI Report. Bergen, Luanda: Chr. Michelsen Institute and CEIC.

Ennes Ferreira, Manuel, and Ricardo Soares de Oliveira. 2019. "The political economy of banking in Angola." African Affairs 118 (470): 49-74.

Hance, William A., and Irene S. van Dongen. 1956. "The port of Lobito and the Benguela railway." Geographical Review 46 (4): 460-487.

Heyman, Josiah, and Howard Campbell. 2009. "The anthropology of global flows a critical reading of Appadurai's 'disjuncture and difference in the global cultural economy."' Anthropological Theory 9 (2): 131-148.

Hönke, Jana, and Ivan Cuesta-Fernandez. 2018. "Mobilising security and logistics through an African port: A controversies approach to infrastructure." Mobilities 13 (2): 246-260.

Inglês, Paulo. 2016. "Reconfiguração social em Angola: Ordem local e quotidiano pós-Conflito" ["Social reconfiguration in Angola: Local order and the post-conflict quotidian"]. PhD diss. Lisbon: ISCTE-IUL.

Jerven, Morten. 2013. Poor numbers: How we are misled by African development statistics and what to do about it. Cornell Studies in Political Economy. Ithaca, NY: Cornell University Press.

Mora, Agathe. 2020. "Black hole state: Human rights and the work of suspension in post-war Kosovo." Social Anthropology 28 (1): 83-95.

Rockefeller, Stuart Alexander. 2015. "'Flow." Current Anthropology 52 (4): 557-578.

Rothenberg, Janell. 2018. “World-world' logistics in Tangier, Morocco." Limn 10: Chokepoints. https://limn.it/articles/chokepoint-sovereignty/. Schouten, Peer, Finn Stepputat, and Jan Bachmann. 
2019. "States of circulation: Logistics off the beaten path." Environment and Planning D: Society and Space 37 (5): 779-793.

Schubert, Jon. 2017. Working the system: A political ethnography of the new Angola. Ithaca, NY: Cornell University Press.

Schubert, Jon. 2018. "Wilful entanglements: Extractive industries and the co-production of sovereignty in Mozambique." Ethnography 21 (4): 537-558.

Schubert, Jon. 2019. "Les « glorieuses familles": Liens de parenté situationnels, stratégie agentielle et critique du pouvoir en Angola." ["The 'glorious families': Situational kinship as agentive strategy and critique of power in Angola"].

Cahiers d'etudes africaines 234 (2): 515-542.
Stenmanns, Julian. 2019. "Logistics from the margins." Environment and Planning D: Society and Space 37 (5): 850-867.

Stenmanns, Julian, and Stefan Ouma. 2015. "The new zones of circulation: On the production and securitization of maritime frontiers in West Africa." In Cargomobilities: Moving materials in a global age, eds. Thomas Birtchnell, Satya Savitsky, and John Urry. London: Routledge, 87-105.

Taylor, Ian. 2016. "Dependency redux: Why Africa is not rising." Review of African Political Economy 43 (147): 8-25.

UNCTAD. n.d. "UNCTAD | Customs AutomationASYCUDA." https://unctad.org/en/Pages/DTL/ TTL/ASYCUDA-Programme.aspx (accessed June 26, 2019). 